\title{
SIDE EFFECTS OF STEROID USE IN PATIENTS WITH TRAUMATIC SPINAL CORD INJURY
}

\author{
EFEITOS COLATERAIS DO USO DE ESTEROIDES EM PACIENTES COM LESÃO MEDULAR TRAUMÁTICA
}

EFECTOS SECUNDARIOS DEL USO DE ESTEROIDES EN PACIENTES CON LÉSION MEDULAR TRAUMÁTICA

Juan Manuel Del Toro Aguayo

\begin{abstract}
Objective: Indicate and identify potential complications in our unit associated with the use of steroids in patients over 16 years of age with traumatic acute spinal cord injury managed with NASCIS II, III scheme compared with patients with the same characteristics who did not receive this management. Methods: To conduct a research study with reports of cases and controls in patients over 16 years of age and with an established diagnosis of acute spinal cord injury, treated definitively in our unit, performing the comparison of evolutionary process between those treated with steroids and those who were not, based on the development of a data collection sheet with several variables.. The results were encoded, tabulated and analyzed. Results: A total of 30 patients were analyzed from January to December 2012 and it was found that $16 \%$ of the patients managed with the steroid scheme required admission to the intensive care unit, $40 \%$ developed hospital-acquired pneumonia, $17 \%$ had urinary tract infection, $3 \%$ progressed to respiratory failure and $20 \%$ of this group had gastrointestinal bleeding. Conclusions: It was concluded that steroid management is not a risk-free therapy and the recommendation is to make a direct assessment of the potential benefit to its use in relation to the possible complications that can ensue before choosing this option in patients with traumatic spinal cord injury.
\end{abstract}

Keywords: Spinal cord injuries; Steroids; Drug-related side effects and adverse reactions.

\section{RESUMO}

Objetivo: Sinalizar e identificar possíveis complicações em nossa unidade, associadas ao uso de esteroides em pacientes com mais de 16 anos de idade com lesão medular aguda manejados com esquema NASCIS II, III em comparação com pacientes com as mesmas características que não receberam esse tratamento. Métodos: Realizar um estudo de investigação com relato de casos e controles em pacientes com mais de 16 anos de idade e com diagnóstico estabelecido de lesão medular traumática aguda, tratados de maneira definitiva em nossa unidade, realizando a comparação do processo evolutivo intra-hospitalar entre os que foram tratados com esteroides e os que não foram, com base na elaboração de uma folha de captura com diversas variáveis. Os resultados foram codificados, tabulados e analisados. Resultados: Um total de 30 pacientes foi analisado no período de janeiro a dezembro de 2012, verificando que dos pacientes tratados com o esquema de esteroides, $16 \%$ precisaram de internação em terapia intensiva, 40\% desenvolveram pneumonia hospitalar, 17\% apresentaram infecção do trato urinário, 3\% evoluíram para insuficiência respiratória e $20 \%$ deste grupo apresentaram sangramento gastrintestinal. Conclusões: Conclui-se que o manejo com esteroides não é uma terapia livre de riscos e se recomenda realizar uma avaliação direta do possível benefício do uso dessa medicação com relação às possíveis complicações que podem sobrevir antes de escolher essa opção em pacientes com lesão medular traumática.

Descritores: Traumatismos da medula espinal; Esteroides; Efeitos colaterais e reações adversas relacionados a medicamentos.

\section{RESUMEN}

Objetivo: Señalar y determinar las posibles complicaciones en nuestra unidad asociadas al uso de esteroides en pacientes mayores de 16 años de edad con lesión medular aguda manejados con esquema NASCIS II, III en comparación con pacientes bajo las mismas características que no recibieron este manejo. Métodos: Realizar un estudio de investigación con reporte de casos y controles en pacientes con diagnostico establecido de lesión medular aguda traumática en mayores de 16 años tratados de manera definitiva en nuestra unidad, realizando una comparativa en el proceso evolutivo intrahospitalario entre aquellos que fueron manejados con esteroides y aquellos que no lo fueron en base a la elaboración de una hoja de captura con diversas variables. Los resultados fueron codificados, tabulados y analizados. Resultados: Se analizó un total de 30 pacientes en el periodo de Enero a Diciembre de 2012 encontrando que aquellos pacientes manejados con esquema de esteroides, un 16\% requirieron atención en terapia intensiva, 40\% desarrollaron neumonía intrahospitalaria, 17\% presentaron infección de vías urinarias, un 3\% cursó con falla respiratoria y $20 \%$ de este grupo presentaron sangrado de tubo digestivo. Conclusiones: Se concluye que el manejo con esteroides no es una terapia libre de riesgo y se hace la recomendación de realizar una evaluación directa del posible beneficio que puede otorgar este manejo contra las potenciales complicaciones a desarrollar antes de elegir esta opción en pacientes con lesión medular traumática.

Descriptores: Traumatismos de la médula espinal; Esteroides; Efectos colaterales y reacciones adversas relacionados con medicamentos.

\section{INTRODUCTION}

Spinal cord injury is usually defined as an injury that partially or completely impairs three main functions: motor, sensory and reflex activities, traumatic injuries being the most frequent. This type of injury has become increasingly common due to the advances in means of transport, as well as in urban communication routes, the development of large cities, and different high-risk occupations. ${ }^{1,2}$ These spinal cord injuries are catastrophic events in patients' lives, and also have a high socioeconomic impact, both for the patient and for the centers where the patients receive medical care. ${ }^{2,3}$

1. Instituto Mexicano del Seguro Social, Centro Médico Nacional de Occidente, Guadalajara, Jalisco, México.

Study conducted at the Orthopedics and Traumatology Service of Hospital de Especialidades of the Centro Médico Nacional de Occidente, Guadalajara, Jalisco, Mexico.

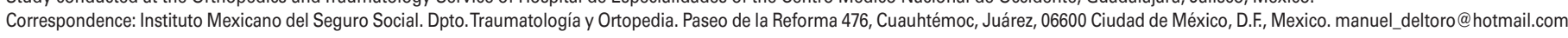


Spinal cord injury is primarily established by a mechanical injury, followed by a secondary, prolonged stage of damage characterized by inflammation, ischemia, edema, damage to the cell membrane, electrolyte disturbances, and release of oxygen free radicals, with the latter leading to cell apoptosis. ${ }^{4,5}$ From a physiopathological perspective, they are distinguished by two distinct stages: Primary (mechanical) injury, in which it causes cell death in the area around the epicenter of the lesion, triggering a second stage in which a vigorous inflammatory reaction occurs in response to the primary injury, subsequently causing demyelization, tissue edema, and cell loss or irreversible cell death. As a general response to trauma, the hypothalamic-pituitary-adrenal axis OKis activated, endogenously releasing cortisol in order to reduce the inflammation and limit cell destruction. ${ }^{5-7}$

Initial treatment protocols for this type of injury have been standardized over time, with special emphasis on the use of steroids, especially methylprednisolone sodium succinate (MPSS), which is a corticosteroid that at pharmacological doses, is indicated in the treatment of disorders and conditions in which anti-inflammatory effects are required. This is due to its potent action as a glucocorticoid as it stimulates the enzyme synthesis necessary to mitigate the inflammatory response, suppressing the migration of polymorphonuclear leukocytes and reversing the increased capillary permeability, while producing effects on the immune system, causing lymphocytopenia, reducing immunoglobulin and the complement levels. It also attenuates the passage of immune complexes through the basement membranes, and depresses tissue reactivity to antigen-antibody interactions. ${ }^{8}$ In the spinal cord trauma per se, and generally speaking, its function is to act as an inflammatory mediator, limiting the release of free radicals and reducing lipid peroxidation with the subsequent side effects.

Several protocols have been widely used in patients with traumatic spinal cord injury, since its description during the eighties, specifically 1984, with the National Association Spinal Cord Injury Study (NASCIS) I trial in which 330 patients with acute spinal cord injury were randomized to receive either a $25 \mathrm{mg}$ or $250 \mathrm{mg}$ dose of MPSS every 6 hours for 10 days, after 100mg bolus with a 6-month follow-up of $54 \%$ of these patients, without evidencing significant differences as regards clinical improvement, yet with the presence of significant side effects. The results of a further trial, NASCIS II, were published in 1992. In this study, three different regimens were administered to three different groups. The first consisted of high doses of MPSS at $30 \mathrm{mg} / \mathrm{kg}$ in bolus to be administered at $15 \mathrm{~min}$ utes and at the first hour, followed by $5.4 \mathrm{mg} / \mathrm{kg} / \mathrm{h}$ infusion for the next 23 hours; the second group received the same regimen for 48 hours, and the last group received Naloxone $5.4 \mathrm{mg} / \mathrm{kg}$ in bolus followed by $4.5 \mathrm{mg} / \mathrm{kg} / \mathrm{h}$ infusion for 23 hours with follow-up of 95\% of the patients per year, showing elevated rates of complications ranging from pneumonia to myopathies in the groups treated with steroids. Finally there is a description of the NASCIS III regimen in which a total of 499 patients at 16 different centers are submitted to the NASCIS II procedure (3 groups), with the difference that the third group received Tirilazad Mesylate instead of Naloxone at a starting dose of $30 \mathrm{mg}$ (MPSS) IV $+2.5 \mathrm{mg} / \mathrm{kg}$ bolus of tirilazad $+2.5 \mathrm{mg} /$ $\mathrm{kg}$ tirilazad boluses every 6 hours for 48 hours, with similar results to the previous studies, and a similar rate of complications. ${ }^{9-11}$

This management was eventually recognized and used across several medical care centers and at highly specialized units in European countries, in the United States, and later on in the rest of the world as standard in the treatment of these injuries. ${ }^{9}$ However, over time it has been seen that management with steroids is not a risk-free therapy, ${ }^{12-14}$ which has sparked intense debate as to its application, with different studies questioning whether it actually represents an advantage in nerve recovery that justifies exposing the patient to the possible side effects associated with this management.

In spite of what is described in the literature, this kind of therapeutic approach has become common practice in our field, without consciously considering the possible complications that could occur in patients. This is despite the existence of several retrospective studies with analysis of databases whose results indicate that the main complications associated with therapeutic regimens that use high doses of steroids are: infection (urinary tract infection, sepsis, pneumonia), respiratory complications (respiratory failure, pulmonary embolism), gastrointestinal bleeding (secondary to gastric ulcer or duodenal ulcer). ${ }^{15-17}$

It should be emphasized that patients who sustain a traumatic spinal cord injury are often the victims of high-energy injuries that generally also involve other organs and systems, determining a diagnosis of polytrauma, and that on multiple occasions require management in intensive care units, situations that make them more liable to suffer complications. ${ }^{18,19}$ Therefore we consider it essential to conduct a comparative study to determine whether those patients treated without steroids suffer the same kind of complications as those receiving steroids. ${ }^{20,21}$

The national incidence of spinal cord injuries in Mexico is estimated at approximately 18.1 per million inhabitants, occurring more frequently between the ages of 16-35 years (productive age) with an average age of 31 years. Comparisons with the United States yield similar results, with males being most affected. ${ }^{22}$

According to statistics, spinal cord injury is a result of road accidents in $37 \%$ of cases, violence in $28 \%$, falls in $21 \%$, sport accidents in $6 \%$ and another $8 \%$ with a prognosis of quadriplegia in more than $50 \%$ of affected patients, a rate that increases in patients over 45 years of age (66\% in patients aged over 60 , and $87 \%$ in those over 75)..$^{22-25}$ This kind of injury requires immediate surgical care in most cases, with decompression and stabilization (either anterior and/or posterior) as applicable, and at the same time, most cases are treated with methylprednisolone sodium succinate, despite the controversy surrounding its administration.

The abovementioned therapeutic regimen is the reason why it is necessary to conduct a comparative study between those patients who were managed under one of the different NASCIS protocols and those who were not, since not only do these complications have important repercussions on the level of possible complications exhibited by patients, but they also require longer hospitalization times, requiring greater capital investments on patient monitoring and medical care. These same complications are also likely to remain as sequelae over extended periods of time, thus completing a cycle in which clinical treatment involves not just the spinal cord injury, but also the possible complications of the additional therapeutic approach, specifically therapy with MPSS. This is why it is essential to carry out a comparative study of the possible sequelae associated with the administration of this drug.

The Hospital de Especialidades Centro Médico Nacional de Occidente Lic. Ignacio García Téllez, where this study is being carried out, has the necessary resources to care for these patients, besides adequately qualified staff with intensive care, a ward, and intermediate therapies for close monitoring of patients who require it. At the same time, as it forms part of a federal health sector, it has access to appropriate medications for the administration of the NASCIS regimen, which consists of saline solutions + ampoules of methylprednisolone sodium succinate and continuous infusion pumps to complete the treatment at 24 or 48 hours as applicable. It also has staff trained in areas other than orthopedics, including internal medicine, pneumology, infectology, angiology, gastroenterology, and a large nursing staff qualified to administer drugs and provide special care to patients.

As this is a retrospective study, with information obtained from clinical records, the possibility must be considered that not all the required information may be available for inclusion of some patients in the study; therefore it may be a smaller sample than expected, and the results may be inconclusive in some cases.

The overall objective will be to point out and determine the possible complications, in our medical unit, associated with the use of steroids in patients over 16 years of age with acute spinal cord injury managed with the NASCIS II, III regimen, as compared to patients with the same characteristics who have not received treatment with steroids. The specific objectives will be to determine which type of 
complication is most prevalent in these groups, and whether there is any difference between the control group and patients treated with MPSS.

\section{MATERIAL AND METHODS}

A case-control study design was drawn up for the patients in the period January 2012 to December 2013 with an established diagnosis of acute traumatic spinal cord injury, aged over 16 and treated definitively at our unit in the department of Traumatology and Orthopedics, considering only those patients who met the criteria for inclusion, exclusion and elimination, at the Hospital de Especialidades Centro Médico Nacional de Occidente Lic. Ignacio García Téllez, and making a comparison in the inpatient evolutionary process between those treated with steroids and those who were not, based on the preparation of a form which includes the patient's details, such as: clinical record, diagnosis, date of admission, date of discharge or death, level of injury, injury development time, surgical treatment requirement, monitoring and management requirement in intensive care, type of NASCIS regimen administered, whether the patient presented any of the variables described in the study (pneumonia, urinary infection, wound infection, unspecified infection at another site, respiratory failure, sepsis, pulmonary embolism, gastrointestinal bleeding), general observations and annotations. The results will subsequently be encrypted, tabulated and analyzed, taking into account the absolute and relative frequencies as well as the measures of association, and making a comparison between the two groups.

It should be mentioned that the hospital where this study is conducted is a tertiary care hospital, which therefore receives patients from various parts of the republic with different medical treatment regimens and evolution times. Therefore, it constantly receives patients with more than 8, 24, 48 and in some cases 72 hours of evolution without steroid therapy. This group of patients functioned as a control group, since they had, in accidental form, not been exposed to high doses of steroids.

\section{Inclusion criteria}

1. Patients aged 16 years and over;

2. A confirmed diagnosis of spinal cord injury on record or based on ICD 10: (G95.9, T09.3, S33.1, S23.1, M513.0);

3. Injury with less than 48 hours of evolution upon receiving care at our unit;

4. Gender: Male and female;

5. Spinal cord injury under treatment with NASCIS II regimen Methylprednisolone succinate $30 \mathrm{mg} / \mathrm{kg}$ bolus followed by $5.4 \mathrm{mg} / \mathrm{kg} /$ hour infusion for the next 23 hours;

6. Spinal cord injury under treatment with NASCIS III regimen (same NASCIS II extended 24 and 48 hours);

7. Spinal cord injury without steroid therapy.

\section{Exclusion criteria (non-inclusion)}

1. Patients under the age of 16 ;

2. Absence of spinal cord injury;

3. Patients treated with lower doses of steroids, or single doses without completing the abovementioned regimens.

\section{Elimination criteria}

1. Injury with more than 48 hours of evolution upon receiving care at our unit:

2. Death within the first 48 hours following administration of the regimen.

For the data collection, the variables to be analyzed are defined as described below:

Nosocomial pneumonia: Nosocomial infection that affects pulmonary parenchyma $72 \mathrm{~h}$ or more after the patient has been admitted to hospital without having the infection prior to admission, and with the following characteristics: ${ }^{26}$
- Chest X-ray or CAT scan with the presence of infiltrate in parenchyma;

- Fever above $38^{\circ} \mathrm{C}$ without another origin;

- Leucopenia below 4,000 $\mathrm{mm}^{3}$ or leukocytosis above $12,000 \mathrm{~mm}^{3}$;

- Purulent sputum or change in sputum characteristics;

- Cough or tachypnea;

- Suggestive auscultation: crackles, rhonchi, wheezing;

- Deterioration in oxygen exchange.

Urinary tract infection: Infection of the urinary tract accompanied by fever, nausea, vomiting, low back pain, general malaise with the following characteristics: ${ }^{27}$

- Urinalysis with the presence of nitrites and leukocyte esterase;

- Positive urine culture.

Surgical wound infection: A wound with the following characteristics:28

- Which heals in the 30 days after surgery (if operated on);

- Compromises skin and subcutaneous soft tissues upon incision, and may involve deep soft tissues (fascia and muscle);

- Purulent drainage;

- Isolation of microorganisms in fluid or tissue;

- Spontaneous dehiscence of superficial or deep sutures;

- Fever above $38^{\circ} \mathrm{C}$;

- Localized pain, irritability upon palpation of the area.

Respiratory insufficiency (failure): Defined as the failure of respiratory system functions secondary to a failure in the exchange of gases: ${ }^{29}$ - Blood gas analysis with alteration in the exchange of gases.

Sepsis: Sepsis is defined as the presence of infection together with a systemic inflammatory response syndrome (SIRS), which are both defined by the presence of the following characteristics: ${ }^{30}$

- Body temperature above $38^{\circ} \mathrm{C}$ or below $36^{\circ} \mathrm{C}$;

- Heart rate above 90 bpm;

- Hyperventilation evidenced by respiratory rate above 20 per minute or PaCO2 below $32 \mathrm{mmHg}$;

- WBC count above 12,000 or below 4,000 cells $\mathrm{mm}^{3}$ with $10 \%$ of immature forms.

Pulmonary Embolism: Total or partial obstruction of the pulmonary artery or its branches caused by clots, air bubbles, fat droplets, amniotic fluid, parasites or tumor cells with the following clinical characteristics: ${ }^{31}$

- Cough, chest pain and/or hemoptysis;

- Blood gas analysis with alteration in gas gradients;

- Chest radiography with atelectasis or abnormalities in pulmonary parenchyma;

- Electrocardiography with T-wave inversion at V1-V4 or signs of right overload (pulmonary p);

- Positive D-dimer result;

- Chest CAT scan with contrast defining presence of emboli in large vessels;

- Pulmonary angiography positive for pulmonary embolism.

Upper gastrointestinal bleeding: Presence of frank bleeding in emesis, as well as melena or coffee-ground vomiting accompanied by decreased hemoglobin, confirmed through esophagogastric endoscopy. ${ }^{32}$

\section{Information collection methods}

A previously prepared form was used that includes the patient's details such as: clinical record, diagnosis (according to ICD-10), date of admission, date of discharge or death, level of injury, injury development time, surgical treatment requirement, monitoring and management requirement in intensive care, type of NASCIS regimen administered, whether the patient presents any of the variables described in the study (pneumonia, urinary infection, wound infection, respiratory failure, sepsis, pulmonary embolism, gastrointestinal bleeding), general observations and notes. This information will be obtained directly from the digital records of the VISTA system, which is considered an electronic record, as well as from the physical records of the patients selected for the protocol. Later on, it will be encrypted and tabulated using EPI INFO software as a work tool. 


\section{RESULTS}

As shown in Table 1, a total sample of 30 patients was analyzed in the period January 2012 to December 2013. These patients were treated at the Orthopedic and Traumatology service of Hospital de Especialidades del Centro Médico Nacional de Occidente, Lic. Ignacio García Téllez of the spinal clinic, 27 (90\%) males and 3 (10\%) females, with ages ranging from $16-70$ years and averaging $37 \pm 16$ years. The hospitalization times of the total sample ranged from one day to 42 days, with an average stay of 18 days \pm 10 days. $97 \%$ of the study population was submitted to surgical treatment. Of the total sample, 16 patients (53\%) received steroid therapy while 14 patients $(47 \%)$ did not; of those patients managed with a steroid regimen, $16 \%$ required intensive care, $40 \%$ developed nosocomial pneumonia, $17 \%$ had urinary tract infection, $3 \%$ developed respiratory failure and finally, $20 \%$ of this group had gastrointestinal bleeding. There were no reports of patients with pulmonary embolism or development of sepsis. In relation to the control group, it was detected that only $3 \%$ required intensive care management, $10 \%$ had urinary tract infection, and $33 \%$ had respiratory failure. There were no reports of

Table 1. Demographic data.

\begin{tabular}{|c|c|c|c|c|c|c|}
\hline Variables & & Abs. Freq. & Rel. Freq. & Variables & Mean & SD \\
\hline \multirow[t]{2}{*}{ Sex } & Femenino & 3 & $90.00 \%$ & Edad & 37.0 & 16.0 \\
\hline & Masculino & 27 & $10.00 \%$ & D. E. & 18.0 & 10.0 \\
\hline \multirow{2}{*}{$\begin{array}{l}\text { Corticosteroid } \\
\text { therapy }\end{array}$} & Yes & 16 & $53.30 \%$ & & & \\
\hline & No & 14 & $46.70 \%$ & & & \\
\hline \multirow{2}{*}{ Intensive Care } & Yes & 6 & $20.00 \%$ & & & \\
\hline & No & 24 & $80.00 \%$ & & & \\
\hline \multirow{2}{*}{ Surgery } & Yes & 29 & $96.70 \%$ & & & \\
\hline & No & 1 & $3.30 \%$ & & & \\
\hline \multirow{2}{*}{ Pneumonia } & Yes & 12 & $40.00 \%$ & & & \\
\hline & No & 18 & $60.00 \%$ & & & \\
\hline \multirow{2}{*}{ Infection (UTI) } & Yes & 8 & $26.70 \%$ & & & \\
\hline & No & 22 & $73.30 \%$ & & & \\
\hline \multirow{2}{*}{$\begin{array}{l}\text { Respiratory } \\
\text { Failure }\end{array}$} & Yes & 1 & $3.30 \%$ & & & \\
\hline & No & 29 & $96.70 \%$ & & & \\
\hline \multirow{2}{*}{ Sepsis } & Yes & 0 & $0.00 \%$ & & & \\
\hline & No & 30 & $100.00 \%$ & & & \\
\hline \multirow{2}{*}{ Embolism } & Yes & 0 & $0.00 \%$ & & & \\
\hline & No & 30 & $100.00 \%$ & & & \\
\hline \multirow{2}{*}{ GI Bleeding } & Yes & 6 & $20.00 \%$ & & & \\
\hline & No & 24 & $80.00 \%$ & & & \\
\hline \multirow{3}{*}{ ASIA } & $A$ & 23 & $76.70 \%$ & & & \\
\hline & $B$ & 4 & $13.30 \%$ & & & \\
\hline & C & 3 & $10.00 \%$ & & & \\
\hline
\end{tabular}

pneumonia, sepsis, pulmonary embolism or gastrointestinal bleeding. (Table 2) Finally, in relation to the degree of neurological involvement using the AMERICAN SPINAL INJURY ASSOCIATION (ASIA) scale, $77 \%$ of patients were classified as ASIA A, 13\% as ASIA B and $10 \%$ as ASIA C.

Table 2. Frequency of adverse events related to the use and omission of steroids in patients with spinal cord trauma.

\begin{tabular}{|c|c|c|c|c|c|c|c|}
\hline Variables & & $\%$ & & $\%$ & OR & $\mathrm{Cl} 95 \%$ & p \\
\hline Intensive Care & Yes & & No & & & & \\
\hline Steroids & 5 & $16.6 \%$ & 11 & $36.7 \%$ & 5.91 & $0.51-55.75$ & $>0.05$ \\
\hline Without Steroids & 1 & $3.3 \%$ & 13 & $43.3 \%$ & & & \\
\hline Pneumonia & Yes & & No & & & & \\
\hline Steroids & 12 & $40.0 \%$ & 4 & $13.3 \%$ & & & $<0.05$ \\
\hline Without Steroids & 0 & $0.0 \%$ & 14 & $46.6 \%$ & & & \\
\hline Infection & Yes & & No & & & & \\
\hline Steroids & 5 & $16.6 \%$ & 11 & $36.7 \%$ & 1.67 & $0.25-11.94$ & $>0.05$ \\
\hline Without Steroids & 3 & $10.0 \%$ & 11 & $36.7 \%$ & & & \\
\hline Respiratory Failure & Yes & & No & & & & \\
\hline Steroids & 1 & $3.3 \%$ & 0 & $0.0 \%$ & & & $>0.05$ \\
\hline Without Steroids & 10 & $33.3 \%$ & 14 & $46.6 \%$ & & & \\
\hline Sepsis & Yes & & No & & & & \\
\hline Steroids & 0 & $0.0 \%$ & 16 & $53.3 \%$ & & & \\
\hline Without Steroids & 0 & $0.0 \%$ & 14 & $46.6 \%$ & & & \\
\hline Embolism & Yes & & No & & & & \\
\hline Steroids & 0 & $0.0 \%$ & 16 & $53.3 \%$ & & & \\
\hline Without Steroids & 0 & $0.0 \%$ & 14 & $46.6 \%$ & & & \\
\hline $\begin{array}{l}\text { Digestive tract } \\
\text { bleeding }\end{array}$ & Yes & & No & & & & \\
\hline Steroids & 6 & $20.0 \%$ & 10 & $33.3 \%$ & & & $>0.05$ \\
\hline Without Steroids & 0 & $0.0 \%$ & 14 & $46.6 \%$ & & & \\
\hline
\end{tabular}

\section{DISCUSSION}

Based on the results of this study, it follows that patients with complete traumatic spinal cord injury who received steroid therapy were 5 times more likely to require treatment in an intensive care unit than those who did not; they also had 1.6 times higher development of urinary tract infections. Hospitalization times were longer in the study group than in the control group, resulting in higher economic investments in this type of patient at our center, taking into account that the daily cost of hospitalization is $\$ 6,377 \mathrm{MXN}$ and the cost per day in the intensive care unit is $\$ 31,525 \mathrm{MXN}$, with a cost per surgical intervention of $\$ 28,370 \mathrm{MXN}$ per episode. Extrapolating these data directly to the case of the patient with the longest hospital stay (42 days), this represents an investment of $\$ 267,834 \mathrm{MNX}$ on the costs of hospitalization alone, according to our calculations, without considering the days on which the patient required intensive care, or the surgical interventions to which this patient was submitted. 


\section{CONCLUSIONS}

Despite the current recommendations of different clinical guidelines on the use of steroids in patients with complete spinal cord injury, this study shows that such management is not a risk-free therapy, and makes it clear that steroids should be used only with full knowledge of the possible complications that may develop in a patient submitted to these regimens, including both the potential repercussions on the patient's health, the impacts on the family environment, and the economic impact on the healthcare system to which the particular patient belongs. It is advisable to weigh the possible benefits of this therapy against the potential complications before choosing steroid therapy in patients with traumatic spinal cord injury.

All authors declare no potential conflict of interest concerning this article.

\section{REFERENCES}

1. Aarabi B, Hadley MN, Dhall SS, Gelb DE, Hurlbert RJ, Rozzelle CJ, et al Management of acute traumatic central cord syndrome (ATCCS). Neurosurgery. 2013;72(Suppl 2):195-204.

2. Jiménez-Avila JM, Alvarez-Garnier JC, Bitar-Alatorre WE. Direct cost of complete cervical spinal cord injury. Acta Ortop Mex. 2012;26(1):10-4

3. Rosińczuk-Tonderys J, Załuski R, Gdesz M, Lisowska A. Spine and spinal cord injuries--causes and complications. Adv Clin Exp Med. 2012;21(4):477-85.

4. Felleiter P, Müller N, Schumann F, Felix O, Lierz P. Changes in the use of the methylprednisolone protocol for traumatic spinal cord injury in Switzerland. Spine (Phila Pa 1976). 2012;37(11):953-6.

5. Schroeder GD, Kwon BK, Eck JC, Savage JW, Hsu WK, Patel AA. Survey of cervical spine research society members on the use of high-dose steroids for acute spinal cord injuries. Spine (Phila Pa 1976). 2014;39(12):971-7.

6. Gorio A, Madaschi L, Di Stefano B, Carelli S, Di Giulio AM, De Biasi S, et al. Methylprednisolone neutralizes the beneficial effects of erythropoietin in experimental spinal cord injury. Proc Natl Acad Sci U S A. 200;102(45):16379-84.

7. Hadley MN, Walters BC, Aarabi B, Dhall SS, Gelb DE, Hurlbert RJ, et al. Clinical assessment following acute cervical spinal cord injury. Neurosurgery. 2013:72(Suppl 2):40-53.

8. Barreras MT. Esteroides en lesion medular postraumatica aguda. Columna. 2011;1(2) 39-42. Disponível em: http://www.medigraphic.com/pdfs/columna/col-2011/col112d.pdf

9. Druschel C, Schaser KD, Schwab JM. Current practice of methylprednisolone administration for acute spinal cord injury in Germany: a national survey. Spine (Phila Pa 1976). 2013;38(11):E669-77.

10. Hurlbert RJ, Hadley MN, Walters BC, Aarabi B, Dhall SS, et al. Pharmacological therapy for acute spinal cord injury. Neurosurgery. 2013;72(Suppl 2):93-105.

11. Hurlbert RJ. The role of steroids in acute spinal cord injury: an evidence-based analysis. Spine (Phila Pa 1976). 2001;26(Suppl 24):S39-46.

12. Leypold BG, Flanders AE, Schwartz ED, Burns AS. The impact of methylprednisolone on lesion severity following spinal cord injury. Spine (Phila Pa 1976). 2007:32(3):373-8.

13. Hall ED. Antioxidant therapies for acute spinal cord injury. Neurotherapeutics. $2011 ; 8(2): 152-67$

14. Hugenholtz $\mathrm{H}$. Methylprednisolone for acute spinal cord injury: not a standard of care. CMAJ. 2003;168(9):1145-6.

15. Chikuda H, Yasunaga H, Takeshita K, Horiguchi H, Kawaguchi H, Ohe K, et al. Mortality and morbidity after high-dose methylprednisolone treatment in patients with acute cervical spinal cord injury: a propensity-matched analysis using a nationwide administrative database. Emerg Med J. 2014;31(3):201-6.

16. Kubeck JP, Merola A, Mathur S, Brkaric M, Majid K, Shanti N, et al. End organ effects of high-dose human equivalent methylprednisolone in a spinal cord injury rat model. Spine (Phila Pa 1976). 2006:31(3):257-61.

17. Chan SC, Chan AP. One-year follow-up of Chinese people with spinal cord injury: a preliminary study. J Spinal Cord Med. 2013;36(1):12-23.

18. Matsumoto T, Tamaki T, Kawakami M, Yoshida M, Ando M, Yamada H. Early complications of high-dose methylprednisolone sodium succinate treatment in the follow-up of acute cervical spinal cord injury. Spine (Phila Pa 1976). 2001;26(4):426-30.

19. Hadley MN, Walters BC. Introduction to the Guidelines for the Management of Acute Cervical Spine and Spinal Cord Injuries. Neurosurgery. 2013;72(Suppl 2):5-16.

20. Postigo RT. Metilprednisolona en el tratamiento del trauma raquimedular. Analisis de la evidencia. Rev Méd Clín Condes. 2006;17(1):12-19.

21. Walters BC. Methodology of the guidelines for the management of acute cervical spine and spinal cord injuries. Neurosurgery. 2013;72(Suppl 2):17-21.

22. Estrada-Mondaca S, Carreón-Rodríguez A, Parra-Cid Mdel C, León Cl, Velasquillo-Martínez C, Vacanti CA, et al. Spinal cord injury and regenerative medicine. Salud Publica Mex. 2007:49(6):437-44

23. Hall ED, Springer JE. Neuroprotection and acute spinal cord injury: a reappraisal. Neur Rx. 2004:1(1):80-100

24. Jiménez-Ávila JM, Calderón-Granados A, Bitar-Alatorre WE. [Direct cost of spinal cord injuries]. Cir Cir. 2012;80(5):435-41

25. van Middendorp JJ, Goss B, Urquhart S, Atresh S, Williams RP, Schuetz M. Diagnosis and prognosis of traumatic spinal cord injury. Global Spine J. 2011;1(1):1-8.

26. Díaz E, Martín-Loeches I, Vallés J. Nosocomial pneumonia. Enferm Infecc Microbiol Clin. 2013;31(10):692-8.

27. Calderón-Jaimes E, Casanova-Román G, Galindo-Fraga A Gutiérrez-Escoto P Landa-Juárez S, Moreno-Espinosa S, et al. Diagnóstico y tratamiento de las infecciones en vías urinarias: un enfoque multidisciplinario para casos no complicados. Bol Med Hosp Infant Mex. 2013:70(1):3-10.

28. Santalla A, López-Criado MS, Ruiz MD, Fernández-Parra J, Gallo JL, Montoy F. Infeccion de la herida quirurgica. Prevencion y Tratamiento. Clin Invest Gin Obst. 2007;34(5):189-96.

29. Fisham AP. Tratado de neumologia. $2^{\text {a }}$. ed. Barcelona: Doyma; 1991.

30. Rodríguez FA, Henao Al, Osorno SC, Jaimes FA. Guía de práctica clínica para el diagnóstico y tratamiento de la sepsis en el servicio de urgencias de adultos. Acta Méd Colomb. 2008;33(3):139-49

31. Gil RD. Embolia pulmonar. Rev Med Clin Condes. 2007:18(2):103-09.

32. Martinez Porras JL, Calleja Panero JL. Hemorrgia digestiva alta: etiologia y procedimientos diagnosticos. Emergencias. 2005;17:S50-4. 